\title{
ANALISIS FAKTOR KESEHATAN DAN KESELAMATAN KERJA (K3) YANG SIGNIFIKAN MEMPENGARUHI KECELAKAAN KERJA PADA PROYEK PEMBANGUNAN APARTEMENT STUDENT CASTLE
}

\author{
Saloni Waruwu, Ferida Yuamita \\ Departement of Industrial Engineering \\ University Technology of Yogyakarta \\ saloni_waruwu@yahoo.com,ferida_yuamita@yahoo.com
}

\begin{abstract}
Health and Safety (K3) is an effort to create a safe working atmosphere, comfortable and achieve the goal of maximum productivity. K3 is very important to be implemented in all areas of employment without exception building projects such as apartments, hotels, malls. However, to prevent any risk of workplace accidents is not as easy as turning the palm of the hand. Occupational accidents disebab by several factors, among others, occupational safety and health training (X1), the commitment of top management (X2), work environment (X3), awareness of workers (X4), regulations and safety and health procedures (X5), availability rambu- occupational health and safety signs (X6) in the workplace, and communication workers (X7). The most significant factor affecting the accidents are the top management commitment (X2) with a value of $36.4 \%$ koefien regression and awareness of workers (X4) of $30.1 \%$. If both of these factors add up the total is $66.5 \%$.
\end{abstract}

Keywords : occupational accident, health and safety factor, significantly.

\section{PENDAHULUAN}

Kesehatan dan Keselamatan Kerja (K3) merupakan upaya untuk menciptakan suasana bekerja yang aman, nyaman dan mencapai tujuan yaitu produktivitas setinggi-tingginya. Kesehatan dan Keselamatan Kerja sangat penting untuk dilaksanakan pada semua bidang pekerjaan tanpa terkecuali proyek pembangunan gedung seperti apartemen, hotel, mall dan lain-lain, karena penerapan K3 dapat mencegah dan mengurangi resiko terjadinya kecelakaan maupun penyakit akibat melakukan kerja. Smith dan Sonesh (2011) mengemukakan bahwa pelatihan kesehatan dan kelelamatan kerja (K3) mampu menurunkan resiko terjadinya kecelakaan kerja. Semakin besar pengetahuan karyawan akan K3 maka semakin kecil terjadinya resiko kecelakaan kerja, demikian sebaliknya semakin minimnya pengetahuan karyawan akan K3 maka semakin besar resiko terjadinya kecelakaan kerja.

Terjadinya kecelakaan kerja dimulai dari disfungsi manajemen dalam upaya penerapan Kesehatan dan Keselamatan Kerja (K3). Ketimpangan tersebut menjadi penyebab dasar terjadinya kecelakaan kerja. Dengan semakin meningkatnya kasus kecelakaan kerja dan kerugian akibat kecelakaan kerja, serta meningkatnya potensi bahaya dalam proses produksi, dibutuhkan pengelolaan K3 secara efektif, menyeluruh, dan terintegrasi dalam manajemen perusahaan. Manajemen K3 dalam organisasi yang efektif dapat membantu untuk meningkatkan semangat pekerja dan memungkinkan mereka memiliki keyakinan dalam pengelolaan organisasi (Akpan, 2011).

Kecelakaan yang terjadi dalam hubungan kerja disebut kecelakaan berhubung dengan hubungan kerja yang artinya kecelakaan tersebut terjadi akibat pekerjaannya baik yang terjadi di tempat kerja maupun hendak pergi/pulang dari tempat kerja. Dalam hal ini kecelakaan kerja dapat terjadi akibat kondisi bahaya yang berkaitan dengan mesin, lingkungan kerja, proses produksi, sifat pekerjaan, dan cara kerja. Kecelakaan kerja bisa juga terjadi akibat tindakan berbahaya yang dalam beberapa hal dapat dilatar belakangi oleh kurangnya pengetahuan dan keterampilan, cacat tubuh, keletihan dan kelelahan/kelesuan, sikap dan tingkah laku yang tidak aman. Kecelakaan kerja tertinggi yaitu terjatuhnya pekerja dengan Risk Level L (Low) sebesar $52 \%$ dan sub kriteria kecelakaa kerja tertinggi yaitu pekerja terjatuh dari tangga dengan Risk Level L (Low) sebesar 52\% (Sepang, 2013). 
Sedangkan faktor penyebab kecelakaan kerja disebabkan oleh faktor manusia (unsafe human acts), berupa tindak perbuatan manusia yang tidak mengalami keselamatan seperti tidak memakai Alat Pelindung Diri (APD), bekerja tidak sesuai prosedur, bekerja sambil bergurau, menaruh alat atau barang tidak benar, sikap kerja yang tidak benar, bekerja di dekat alat yang berputar, kelelahan, kebosanan dan sebagainya. Selain faktor manusia juga disebabkan faktor lingkungan (unsafe condition), berupa keadaan lingkungan yang tidak aman, seperti mesin tanpa pengaman, peralatan kerja yang sudah tidak baik tetapi masih dipakai, penerangan yang kurang memadai, tata ruang kerja tidak sesuai, cuaca, kebisingan, dan lantai kerja licin. Pengendalian risiko yang dapat dilakukan pada risiko terjadinya kecelakaan kerja adalah inspeksi K3 harian untuk pemakaian APD (Alat Pelindung Diri) lengkap, memperketat pengawasan manajemen terhadap pekerja yang tidak memakai alat pelindung diri, menyediakan dan melengkapi rambu-rambu keselamatan di proyek konstruksi (Sepang, 2013). Hal ini sesuai dengan undang-undang No. I tahun 1970 Tentang Keselamatan Kerja. Pemberian APD pada karyawan harus diikuti dengan prosedur dasarnya dan diinformasikan akan bahaya yang diakibatkan serta dilatih bagaimana cara memakai serta merawat yang benar.

PT. Adhi Karya (persero) Tbk. Divisi Konstruksi IV Proyek Pembangunan Apartement Student Castle, sebagai perusahaan yang bergerak dalam konstruksi tidak pernah terlepas dari resiko kecelakaan kerja. Resiko kecelakaan kerja pada proyek pembangunan apartement student castle terjadi pada saat pekerjaan urugan tanah/pasir, pekerjaan pemasangan kolom, fabrikasi besi dan bekisting, penggunaan scaffolding dari pemasangan hingga pembongkaran, kegiatan alat bantu pengangkatan (tower crane), penggunaan alat berat yang berisiko tinggi, pekerjaan cable duct, pekerjaan penggalian dan pekerjaan pengelasan.

Berdasarkan permasalahan yang telah dijelaskan pada latar belakang, maka dapat ditarik suatu rumusan masalah sebagai berikut:

1. Faktor-faktor apa saja yang mempengaruhi kesehatan dan keselamatan kerja pada proyek konstruksi?

2. Apa faktor yang paling signifikan mempengaruhi kecelakaan kerja pada proyek konstruksi?

3. Bagaimana cara untuk meminimalisir risiko terjadinya kecelakaan kerja pada proyek konstruksi?

\section{LANDASAN TEORI}

\section{A. Kesehatan dan Keselamatan Kerja}

Dalam undang-undang nomor 23 tahun 1992, pasal 23 tentang Kesehatan dan Keselamatan Kerja (K3) disebutkan bahwa Kesehatan dan Keselamatan Kerja (K3) diselenggarakan untuk mewujudkan produktivitas kerja secara optimal yang meliputi pelayanan kesehatan dan pencegahan penyakit akibat kerja.

Ervianto (2005) mengatakan bahwa elemen-elemen yang patut dipertimbangkan dalam mengembangkan dan mengimplementasikan program $\mathrm{K} 3$ adalah sebagai berikut:

1. Komitmen perusahaan untuk mengembangkan program yang mudah dilaksanakan.

2. Kebijakan pimpinan tentang Keselamatan dan Kesehatan Kerja (K3).

3. Ketentuan penciptaan lingkungan kerja yang menjamin terciptanya K3 dalam bekerja.

4. Ketentuan pengawasan selama proyek berlangsung.

5. Pendelegasian wewenang yang cukup selama proyek berlangsung.

6. Ketentuan penyelenggaraan pelatihan dan pendidikan.

7. Pemeriksaan pencegahan terjadinya kecelakaan kerja.

8. Melakukan penelusuran penyebab utama terjadinya kecelakaan kerja.

9. Mengukur kinerja program keselamatan dan kesehatan kerja.

10. Pendokumentasian yang memadai dan pencacatan kecelakaan kerja secara kontinu. 
Jenis-jenis kecelakaan yang terjadi pada bidang industri konstruksi adalah antara lain sebagai berikut:

1. Jatuh terpeleset.

2. Kejatuhan barang dari atas.

3. Terinjak.

4. Terkena barang yang runtuh atau roboh.

5. Kontak dengan suhu panas atau suhu dingin.

6. Terjatuh, dan terguling.

7. Terjepit, dan terlindas.

8. Tertabrak.

9. Tindakan yang tidak benar.

10. Terkena benturan keras.

Usaha-usaha pencegahan timbulnya kecelakaan kerja perlu dilakukan sedini mungkin. Adapun tindakan yang bisa dilakukan adalah sebagai berikut:

1. Mengidentifikasikan setiap jenis pekerjaan yang beresiko dan mengelompokkannya sesuai tingkat resikonya.

2. Adanya pelatihan bagi para pekerja konstruksi sesuai keahliannya.

3. Melakukan pengawasan secara lebih intensif terhadap pelaksanaan pekerjaan.

4. Menyediakan alat perlindungan kerja selama durasi proyek.

5. Melaksanakan pengaturan dilokasi proyek konstruksi.

\section{B. Alat Pelindung Diri (APD)}

Alat Pelindung Diri (APD) merupakan cara terakhir yang harus dilakukan untuk mencegah kecelakaan apabila program pengendalian lain tidak mungkin dilaksanakan, artinya untuk mencegah terjadinya kecelakaan kerja hendaknya dianalisis sedemikian rupa sehingga sistem kerja tidak mendatangkan akibat negatif terhadap para pekerja. Namun jika pencegahan lainnya tidak dapat diefektifkan maka alat pelindung dirilah yang akan dilakukan, Suma'mur (1992).

Alat pelindung diri yang sering digunakan antara lain:

1. Helm, melindungi kepala terhadap kemungkinan tertimpa benda jatuh atau menghindari cedera kepala akibat benturan benda berat.

2. Earplug/earmuff, sebagai alat pelindung telinga karena bekerja di daerah kebisingan akibat penggerindaan dan pemukulan.

3. Sarung tangan, melindungi jari dan tangan pekerja dari goresan, benturan dan pengaruh sinar las. Sarung tangan terbuat dari kain yang nyaman serta memungkinkan jari dan tangan bergerak bebas. Untuk melindungi dari pengaruh sinar las maka sarung tangan terbuat dari kulit.

4. Masker, untuk melindungi pernafan dan wajah dari pengaruh sinar pada saat bekerja.

5. Apron, baju panjang dari bahan karet timbal dengan daya serap radiasi.

6. Safety belt, berguna untuk melindungi diri dari kemungkinan terjatuh, biasanya digunakan pada pekerjaan konstruksi dan memanjat serta tempat tertutup atau boiler. Harus dapat menahan beban sebesar $80 \mathrm{Kg}$.

7. APD untuk tugas khusus, terdiri dari:

a. Alat pelindung kepala

b. Topi pelindung/pengaman (safety helmet): melindungi kepala dari benda keras, pukulan dan benturan, terjatuh dan terkena arus listrik.

c. Tutup kepala: melindungi kepala dari kebakaran, korosif, uap-uap, panas/dingin.

d. Hats/cap: melindungi kepala dari kotoran debu atau tangkapan mesin-mesin berputar. 


\section{Kerugian Akibat Kecelakaan Kerja} terdiri atas:

Kecelakaan kerja dapat menyebabkan kerugian. Kerugian-kerugian tersebut

1. Kerusakan, merupakan kerugian yang berdampak pada peralatan atau mesin yang digunaka dalam kerja atau pada hasil produksi.

2. Kekacauan organisasi, merupakan kerugian yang berdampak karena adanya keterlambatan proses, pengantian alat atau tenaga kerja baru.

3. Keluhan dan kesedihan, merupakan kerugian non material yang diderita oleh tenaga kerja namu lebih cenderung pada kerugian yang bersifat psikis.

4. Kelainan dan cacat, merupaka kerugian yang diderita tenaga kerja secara fisik, bisa berupa sakit yang terobati atau yang lebih fatal adalah kelainan dan cacat.

5. Kematian, merupakan kerugian yang menduduki posisi puncak terhadap fisik dan psikis tenaga kerja.

\section{Pencegahan Kecelakaan Kerja} berikut:

Ada beberapa cara untuk mencegah terjadinya kecelakaan kerja yakni sebagai

1. Peraturan Perundangan, yaitu ketentuan-ketentuan yang diwajibkan mengenai kondisi-kondisi kerja pada umumnya, perencanaan, konstruksi, perawatan/pemeliharaan, pengawasan, pengujian dan cara kerja peralatan industri, tugas-tugas pengusaha dan buruh, latihan, supervisi medis, PPPK, dan pemeliharaan kesehatan.

2. Standarisasi, yaitu penetapan standar-standar resmi, setengah resmi atau tidak resmi, misalnya konstruksi yang memenuhi syarat-syarat keselamatan jenis peralaan industri tertentu, praktik keselamatan, atau peralatan perlindugan diri.

3. Pengawasan, tentang dipatuhinya ketentun perundangan yang diwajibkan.

4. Penelitian bersifat teknis, yang meliputi sifat dan ciri-ciri bahan yang berbahaya, penyelidikan tentang pagar pengaman, pengujian alat perlindungan diri.

5. Riset medis, yang meliputi terutama penelitian tentang efek fisiologis dan patologis faktor lingkungan, teknologis, dan keadaan fisik yang mengakibatkan kecelakaan.

6. Penelitian psikologis, yaitu penyelidikan tentang pola kejiwaan yang meyebabkan terjadinya kecelakaan.

7. Penelitian secara statistik, untuk menetapkan jenis kecelakaan yang terjadi, dalam pekerjaan apa dan sebab-sebabnya.

8. Pendidikan, yang menyangkut tentang pendidikan keselamatan dalam kurikulum teknik sekolah perniagaan atau kursus pertukangan.

9. Pengarahan, yaitu penggunaan aneka cara penyuluhan atau pendekatan lain untuk menimbulkan sikap untuk selamat.

10. Asuransi, yaitu insentif financial untuk mningkatkan pencegahan kecelakaan kerja, misalnya dalam bentuk pengurangan premi yang dibayar oleh perusahaan, jika tindakan-tindakan keselamatan sangat baik.

11. Usaha keselamatan pada tingkat perusahaan, yang merupakan ukura utama efektif tidaknya peneraapan keselamatan kerja. Pada perusahaan kecelakaan terjadi, sedangkan pola kecelakaan pada suatu perusahaan sangat tergantung pada tingkat kesadaran atau keselamatan kerja oleh semua pihak yang bersangkutan.

\section{E. Tenaga Kerja Bangunan}

Tenaga kerja bangunan dapat dibedakan menjadi tenaga kerja bangunan biasa, tukang batu, tukang kayu, tukang angkat dan angkut, mandor, pengawas lapangan, dan kontraktor adalah tenaga kerja bangunan. Dalam pelaksanaan pekerjaan bangunan sangat sering mengalami kecelakaan seperti terjatuh, tertimpa, terpeleset, terpotong, tertusuk oleh material bangunan. 


\section{F. Analisis Faktor}

Analisis faktor merupakan salah satu teknik analisis statistika multivariate, dengan menitiberatkan pada data yang mempunyai hubungan yang sangat erat secara bersama-sama pada segugusan variabel tanpa membedakan antara variabel tergantung atau variabel endogen $\mathrm{Y}$ dan variabel bebas atau variabel eksogen X. Analisis faktor digunakan sebagai input dalam membangun analisis regresi yang lebih lanjut.

Pada dasarnya analisis faktor atau analisis komponen utama mendekatkan data pada suatu pengelompokkan atau pembentukan suatu variabel baru yang berdasarkan adanya keeratan hubungan antar demensi pembentuk faktor, dari sejumlah variabel $p$ yaitu sebanyak 7 faktor akan direduksi menjadi sebanyak $\mathrm{k}=2$ buah faktor yang dapat menerangkan ketujuh item faktor semula. Dalam hal ini $\mathrm{k}$ buah faktor dapat mewakili $\mathrm{p}$ buah faktor asalnya, sehingga lebih sederhana. Model umum analisis faktor adalah sebagai berikut.

$\mathrm{X}_{1}=\mathrm{C}_{11} \mathrm{~F}_{1}+. . .+\mathrm{C}_{1 \mathrm{~m}} \mathrm{~F}_{\mathrm{m}}+\varepsilon_{1}$

$\mathrm{X}_{2}=\mathrm{C}_{21} \mathrm{~F}_{1}+\ldots+\mathrm{C}_{2 \mathrm{~m}} \mathrm{~F}_{\mathrm{m}}+\varepsilon_{2}$

$\mathrm{X}_{\mathrm{p}}=\mathrm{C}_{\mathrm{p} 1} \mathrm{~F}_{1}+\ldots .+\mathrm{C}_{\mathrm{pm}} \mathrm{F}_{\mathrm{m}}+\varepsilon_{\mathrm{p}}$

Dimana:

$\mathrm{X}=$ variabel eksogen

$\mathrm{F}_{\mathrm{j}} \quad=$ faktor bersama ke- $\mathrm{j}$

$\mathrm{C}_{\mathrm{ij}}=$ parameter yang merefleksikan pentingnya faktor ke-j dalam komposisi dari respons ke-i.

$\varepsilon_{\mathrm{i}} \quad=$ galat dari respons ke-i

\section{G. Analisis Regresi}

Analisis regresi digunakan untuk memprediksikan seberapa jauh perubahan nilai variabel dependen, bila nilai variabel independen dimanipulasi/diubah-ubah atau dinaikturunkan (Sugiyono, 2011 : 260). Persamaan rumus regresi linear ganda dengan dua prediktor dapat dirumuskan sebagai berikut:

$\mathrm{Y}=\mathrm{a}+\mathrm{b}_{1} \mathrm{X}_{1}+\mathrm{b}_{2} \mathrm{X}_{2}$

Dimana:

$\mathrm{Y}=$ subyek dalam variabel dependen yang diprediksikan.

a = harga $\mathrm{Y}$ ketika harga $\mathrm{X}=0$ (harga konstan)

$\mathrm{b}$ = angka arah atau koefien regresi, yang menunjukkan angka peningkatan atau penurunan variabel dependen yang didasarkan pada perubahan variabel independen.

$\mathrm{X}=$ subyek dalam variabel independent yang mempunyai nilai tertentu.

Untuk menghitung harga $a, b_{1}, b_{2}$ dapat dilakukan dengan menggunakan persamaan berikut.

$\left.Y=\mathrm{an}+\mathrm{b}_{1} \quad X_{1}+\mathrm{b}_{2} \quad X_{2}\right)$

$X_{1} \mathrm{Y}=\mathrm{a} \quad X_{1}+\mathrm{b}_{1} \quad X_{1}^{2}+\mathrm{b}_{2} \quad X_{1} X_{2}$

$X_{2} \mathrm{Y}=\mathrm{a} \quad X_{2}+\mathrm{b}_{1} \quad X_{1} X_{2}+\mathrm{b}_{2} \quad X_{2}^{2}$ 


\section{METODOLOGI PENELITIAN}

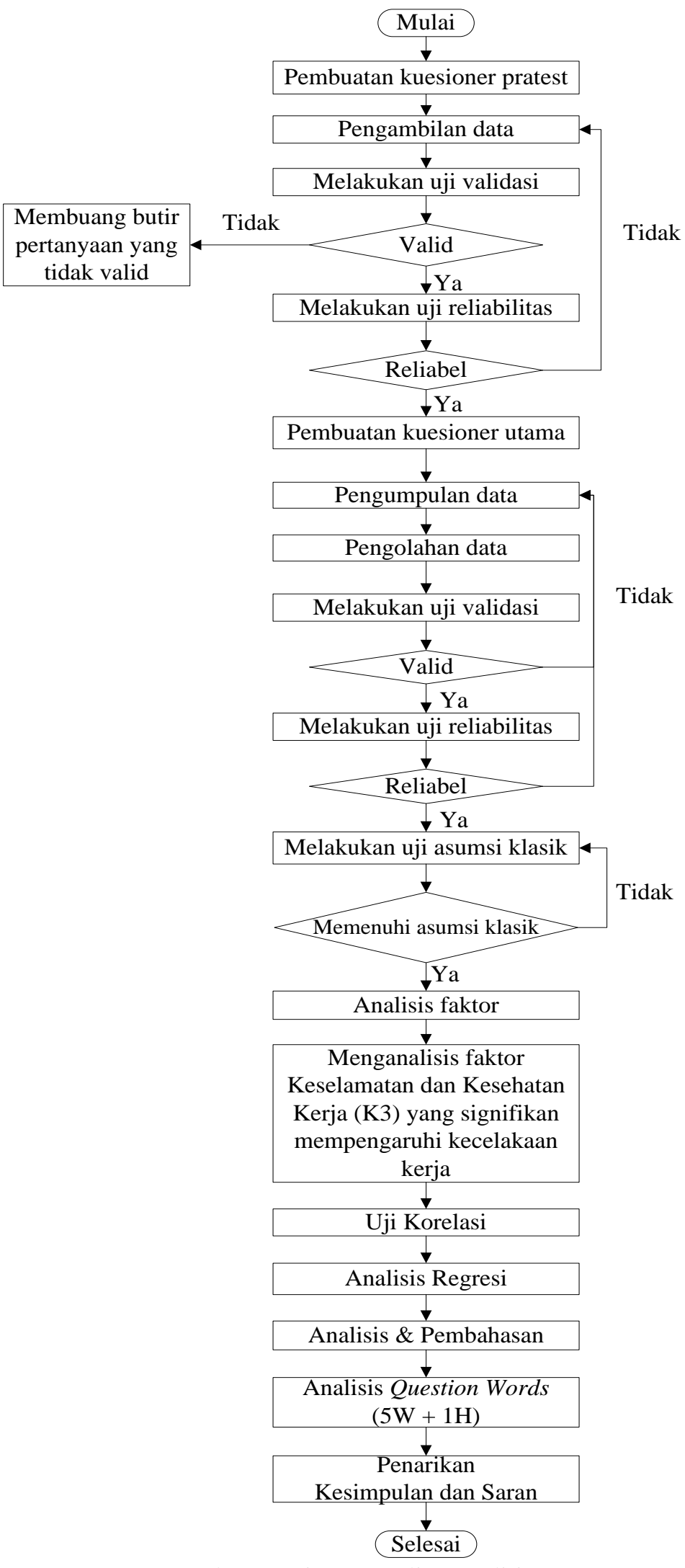

Gambar 1. Diagram Alir Penelitian 


\section{HASIL DAN PEMBAHASAN}

\section{A. Karakteristik Responden}

Responden dalam ini penelitian ini adalah staf divisi Health Safety Equipment (HSE) sebanyak 3 orang dan sisanya adalah karyawan tenaga kerja bangunan PT. Adhi Karya (persero) Tbk. Divisi Konstruksi IV Proyek Pembangunan Apartement Student Castle. Sebagaimana yang akan dijelaskan pada tabel-tabel berikut.

\section{Umur Responden}

Tabel 1 Umur Responden

\begin{tabular}{|c|c|c|c|}
\hline No. & Umur (tahun) & Frekuensi & Persentase (\%) \\
\hline 1 & $\leq 20$ & 0 & 0 \\
\hline 2 & $21-30$ & 20 & 25 \\
\hline 3 & $31-40$ & 35 & 43,75 \\
\hline 4 & $41-50$ & 20 & 25 \\
\hline 5 & $\geq 51$ & 5 & 6,25 \\
\hline \multicolumn{2}{r|}{ Total } & $\mathbf{8 0}$ & $\mathbf{1 0 0}$ \\
\hline
\end{tabular}

Berdasarkan Tabel 1 dapat dilihat bahwa karyawan yang bekerja di PT. Adhi Karya (persero) Tbk. Divisi Konstruksi IV Proyek Pembangunan Apartement Student Castle merupakan usia yang sangat produktif. Karyawan yang berusia 21 tahun - 30 tahun sebanyak $25 \%$, usia 31 tahun - 40 tahun sebanyak $43,75 \%$, usia 41 tahun - 50 sebanyak $25 \%$, sedangkan usia diatas 52 sebanyak $6,25 \%$.

\section{Tingkat Pendidikan}

Tabel 2 Jenjang Pendidikan Responden

\begin{tabular}{|c|c|c|c|}
\hline No. & Tingkat pendidikan & Frekuensi & Persentase (\%) \\
\hline 1 & SD & 5 & 6,25 \\
\hline 2 & SMP & 10 & 12,5 \\
\hline 3 & SMA & 30 & 37,5 \\
\hline 4 & STM & 12 & 15 \\
\hline 5 & SMK & 20 & 25 \\
\hline 6 & D3 & 2 & 2,5 \\
\hline 7 & S1 & 1 & 1,25 \\
\hline \multicolumn{2}{|c|}{ Total } & $\mathbf{8 0}$ & $\mathbf{1 0 0}$ \\
\hline
\end{tabular}

Berdasarkan Tabel 2 dapat dilihat bahwa karyawan yang bekerja di PT. Adhi Karya (persero) Tbk. Divisi Konstruksi IV Proyek Pembangunan Apartement Student Castle merupakan orang-orang yang sudah berpendikan. Jenjang pendidikan paling banyak adalah lulusan SMA dengan persentase sebesar 37,5\%.

\section{Pengalaman Kerja}

Tabel 3 Pengalaman Kerja Responden

\begin{tabular}{|c|c|c|c|}
\hline No. & Pengalaman kerja & Frekuensi & Persentase (\%) \\
\hline 1 & $\leq 1$ & 7 & 8,75 \\
\hline 2 & $\leq 2$ & 15 & 17,75 \\
\hline 3 & $\leq 3$ & 18 & 22,5 \\
\hline 4 & $\leq 4$ & 31 & 38,75 \\
\hline 5 & $\geq 5$ & 9 & 11,25 \\
\hline \multicolumn{2}{|r|}{ Total } & 80 & 100 \\
\hline
\end{tabular}


Berdasarkan Tabel 3 dapat dilihat bahwa karyawan yang bekerja di PT. Adhi Karya (persero) Tbk. Divisi Konstruksi IV Proyek Pembangunan Apartement Student Castle. Berdasarkan hasil penyebaran kuesioner karyawan yang memiliki pengalaman kerja $\leq 2$ tahun lebih cenderung mengalami kecelakaan kerja.

\section{B. Pengolahan Data}

Teknik pengolahan data dalam penelitian ini secara umum dibagi dalam lima tahap yakni tahap pengkodean (coding), uji validasi, uji reliabilitas, uji asumsi klasik, dan analisis regresi linear berganda. Alur logika pengolahan data akan dijelaskan pada Gambar 2.

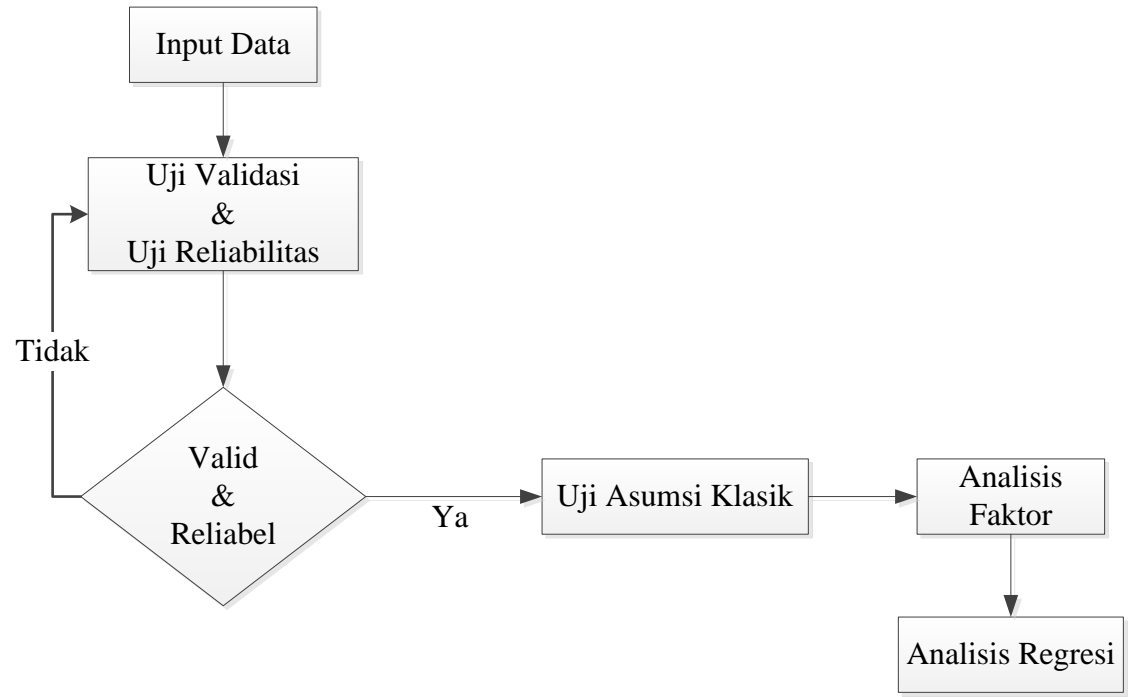

Gambar 2 Alur Pengolahan Data

\section{Uji Validasi}

Uji validitas dilakukan menggunakan software SPSS 16.00 dengan membandingkan nilai $\mathrm{r}$ hitung (pearson correlation) pada kolom total correlation dengan nilai r-tabel $(\mathrm{r}$-tabel $=\mathrm{N}-2$ ) dengan taraf kesalahan 5\% (taraf kepercayaan $95 \%$ ) dan $\mathrm{N}=80$, maka nilai $\mathrm{r}$-tabel $=0,227$. Hasil dari uji validasi akan dijelaskan pada Tabel 4 dengan asumsi bahwa:

Jika r-hitung > r-tabel maka butir pertanyaan dinyatakan valid Jika r-hitung < r-tabel maka butir pertanyaan dinyatakan tidak valid

Tabel 4 Hasil Uji Validasi

\begin{tabular}{|c|c|c|c|}
\hline Variabel & r-hitung & r-tabel & Status \\
\hline$X_{1}$ & 0,686 & 0,227 & Valid \\
\hline$X_{2}$ & 0,534 & 0,227 & Valid \\
\hline$X_{3}$ & 0,562 & 0,227 & Valid \\
\hline$X_{4}$ & 0,512 & 0,227 & Valid \\
\hline$X_{5}$ & 0,692 & 0,227 & Valid \\
\hline$X_{6}$ & 0,625 & 0,227 & Valid \\
\hline$X_{7}$ & 0,481 & 0,227 & Valid \\
\hline$Y_{1}$ & 0,427 & 0,227 & Valid \\
\hline$Y_{2}$ & 0,474 & 0,227 & Valid \\
\hline$Y_{3}$ & 0,549 & 0,227 & Valid \\
\hline$Y_{4}$ & 0,415 & 0,227 & Valid \\
\hline$Y_{5}$ & 0,518 & 0,227 & Valid \\
\hline$Y_{6}$ & 0,546 & 0,227 & Valid \\
\hline
\end{tabular}


Pada Tabel 4 dijelaskan bahwa nilai r-hitung dari semua variabel lebih besar dari r-tabel (r-hitung > r-tabel), sehingga semua variabel dianggap valid dan bisa digunakan untuk digunakan dalam penelitian untuk melakukan analisis selanjutnya.

\section{Uji Reliabilitas}

Hasil uji reliabilitas akan dijelaskan pada Tabel 5.

Tabel 5 Hasil Uji Reliabilitas

\begin{tabular}{|c|c|c|}
\hline Variabel & Cronbach's Alpha & Keterangan \\
\hline $\mathrm{X}$ & 0,681 & Realiabel \\
\hline $\mathrm{Y}$ & 0.654 & Realiabel \\
\hline
\end{tabular}

Pada Tabel 5 menunjukkan bahwa variabel yang diteliti memiliki nilai Cronbach's Alpha di atas 0.601 sehingga semuanya dianggap reliabel, dan dapat digunakan untuk tahap analisis selanjutnya.

\section{Uji Asumsi Klasik}

Model regresi linear berganda akan menghasilkan perhitungan yang lebih akurat apabila asumsi-asumsi uji autokorelasi, uji normalitas, uji multikolinearitas, uji linieritas, terpenuhi.

a. Uji Autokorelasi

Uji autokorelasi menggunakan Uji Durbin-Watson (DW test) antara faktor Keselamatan dan Kesehatan Kerja (K3) dengan kecelakaan kerja akan dijelaskan pada Tabel 4.10, dengan uji hipotesis sebagai berikut:

Ho : tidak ada autokorelasi $(\mathrm{r}=0)$

$\mathrm{Hi}$ : ada autokorelasi $(\mathrm{r} \neq 0)$

Tabel 6 Uji Autokorelasi

\begin{tabular}{|c|c|c|c|c|c|}
\hline Model & $\mathbf{R}$ & $\mathbf{R}$ Square & $\begin{array}{c}\text { Adjusted R } \\
\text { Square }\end{array}$ & $\begin{array}{c}\text { Std. Error of } \\
\text { the Estimate }\end{array}$ & $\begin{array}{c}\text { Durbin- } \\
\text { Watson }\end{array}$ \\
\hline 1 & 0.821 & 0.674 & -0.011 & 0.436 & 1.089 \\
\hline
\end{tabular}

Nilai Durbin - Watson pada uji autokorelasi di Tabel 5 sebesar 1,089 nilai tersebut akan dibandingkan dengan nilai tabel dengan taraf signifikansi sebesar 5\%, jumlah observasi ( $\mathrm{df}=\mathrm{n}-2=80-2=78$ ) dan jumlah variabel independen $7(\mathrm{k}=7)$, maka di tabel Durbin-Watson diperoleh nilai batas atas $(\mathrm{du})=1,831$ dan nilai batas bawah $(\mathrm{dl})=1,453$ dan nilai $\mathrm{d}=1,089$. Karena $\mathrm{d}<$ dl maka kesimpulannya terdapat autokorelasi positif.

\section{b. Uji Multikolinearitas}

Uji multikolinearitas bertujuan untuk menguji adanya korelasi antara variabel bebas pada model regresi.

Tabel 7 Uji Multikolinearitas

\begin{tabular}{|c|c|c|c|}
\hline \multirow{2}{*}{\multicolumn{2}{|c|}{ Model }} & \multicolumn{2}{|c|}{ Collinearity Statistics } \\
\hline & & Tolerance & VIF \\
\hline \multirow[t]{4}{*}{1} & (Constant) & & \\
\hline & Pelatihan K3 & 0.167 & 5.972 \\
\hline & Komitmen Top Manajemen & 0.122 & 8.199 \\
\hline & Lingkungan Kerja & 0.743 & 1.346 \\
\hline
\end{tabular}




\begin{tabular}{|l|l|c|c|}
\hline Kesadaran Pekerja & 0.125 & 7.972 \\
\cline { 2 - 4 } Peraturan \& Prosedur K3 & 0.201 & 4.968 \\
\cline { 2 - 4 } Rambu-Rambu K3 & 0.647 & 1.545 \\
\hline Komunikasi Pekerja & 0.844 & 1.184 \\
\hline
\end{tabular}

Dari hasil uji multikolinearitas dengan menggunakan SPSS 16.00 nilai VIF berada antara 1-10, oleh sebab karena itu penelitian ini tidak ada persoalan multikolinearitas, dimana persyaratan untuk dapat dikatakan terbebas dari multikolinieritas adalah apabila nilai VIF prediktor 1-10.

\section{c. Uji Linieritas}

Uji linieritas dilakukan untuk mengetahui hubungan antara variabel independent (bebas) dan dependent (terikat) mempunyai hubungan yang linier atau tidak secara signifikan. Untuk melihat hubungan linieritas berdasarkan uji $\mathrm{F}$ atau membandingkan nilai signifikansi (Sig.) dengan taraf error sebesar 5\%. Jika nilai Sig.<0,05, maka model regresi adalah linier.

Tabel 8 Uji Linearitas

\begin{tabular}{|l|l|l|l|l|l|c|}
\hline \multicolumn{2}{|c|}{ Model } & \multicolumn{1}{|c|}{$\begin{array}{c}\text { Sum of } \\
\text { Squares }\end{array}$} & df & Mean Square & F & Sig. \\
\hline \multirow{4}{*}{1} & Regression & 0.728 & 2 & 0.364 & 3.981 & 0.001 \\
\cline { 2 - 8 } & Residual & 14.159 & 77 & 0.184 & & \\
\cline { 2 - 7 } & Total & 14.888 & 79 & & & \\
\hline
\end{tabular}

Berdasarkan Tabel 8 nilai $0,001<0,05$ sehingga model persamaan regresi berdasarkan data penelitian memenuhi asumsi linieritas, artinya memiliki hubungangan yang saling terkait antara variabel bebas (X) dan variabel terikat $(\mathrm{Y})$.

\section{d. Uji Normalitas}

Berdasarkan perhitungan rasio skewness dan rasio kurtosis menunjukkan bahwa residual berdistribusi normal. Untuk meyakinkan bahwa data residual terdistribusi secara normal, perlu dilakukan Uji KolmogorovSmirnov yang ditunjukkan pada Tabel 9

Tabel 9 Tests of Normality

\begin{tabular}{|l|c|c|c|}
\hline \multirow{2}{*}{} & \multicolumn{3}{|c|}{ Kolmogorov-Smirnov ${ }^{\boldsymbol{a}}$} \\
\cline { 2 - 4 } & Statistic & df & Sig. \\
\hline Pelatihan K3 & 0.295 & 80 & 0.000 \\
\hline Komitmen Top Manajemen & 0.235 & 80 & 0.000 \\
\hline Lingkungan Kerja & 0.271 & 80 & 0.000 \\
\hline Kesadaran Pekerja & 0.228 & 80 & 0.000 \\
\hline Peraturan \& Prosedur K3 & 0.351 & 80 & 0.000 \\
\hline Rambu-Rambu K3 & 0.205 & 80 & 0.000 \\
\hline Komunikasi Pekerja & 0.303 & 80 & 0.000 \\
\hline Kecelakaan Kerja & 0.422 & 80 & 0.000 \\
\hline
\end{tabular}


Pada Tabel 9 terlihat bahwa nilai signifikansi sebesar $0,000<0,05$ yang berarti nilai residual terdistribusi secara normal atau memenuhi asumsi klasik normalitas residual.

\section{e. Uji Homogenitas}

Uji homogenitas dilakukan untuk mengetahui apakah dua atau lebih kelompok data sampel berasal dari populasi yang memiliki variansi yang sama.

Hipotesis yang diuji ialah:

$\mathrm{H}_{0}$ : Variansi pada tiap kelompok sama (homogen)

$\mathrm{H}_{1}$ : Variansi pada tiap kelompok tidak sama (tidak homogen)

Jika nilai signifikansi (sig.) $>\alpha$, maka $\mathrm{H}_{0}$ dapat diterima.

Jika nilai signifikasi (sig.) $<\alpha$, maka $\mathrm{H}_{0}$ tidak dapat diterima.

Tabel 10 Test of Homogeneity of Variances

\begin{tabular}{|l|c|c|}
\hline & Levene Statistic & Sig. \\
\hline Pelatihan K3 & 0.415 & 0.662 \\
\hline Komitmen Top Manajemen & 0.171 & 0.843 \\
\hline Lingkungan Kerja & 0.844 & 0.434 \\
\hline Kesadaran Pekerja & 0.266 & 0.767 \\
\hline Peraturan \& Prosedur K3 & 0.419 & 0.659 \\
\hline Rambu-Rambu K3 & 0.879 & 0.419 \\
\hline Komunikasi Pekerja & 1.967 & 0.147 \\
\hline
\end{tabular}

Berdasarkan hasil yang diperoleh pada test of homogenity of variances pada Tabel $10 \mathrm{di}$ atas menunjukkan hasil uji homogenitas dengan nilai $\alpha$ sebesar 0,05 diperoleh taraf signifikansi > 0,05, maka dapat disimpulkan hipotesis nol (Ho) diterima, artinya variansi setiap sampel sama (homogen).

\section{Analisis Faktor}

\section{a. Analisis Faktor Utama}

Pada analisis multivariate diperlukan suatu penyederhanaan dalam struktur atau dimensi data, sehingga keragaman data dapat dijelaskan lebih sederhana. Dalam analisis variabel utama, dari beberapa buah variabel utama dipilih $\mathrm{k}$ variabel utama yang telah mampu menjelaskan keragaman data.

\begin{tabular}{|c|c|c|c|}
\multicolumn{4}{c}{ Tabel 11 Hasil Analisis Faktor } \\
\hline \multirow{3}{*}{ Total Variance Explained } \\
\hline \multirow{3}{*}{ Component } & \multicolumn{3}{|c|}{ Initial Eigenvalues } \\
\cline { 2 - 4 } & Total & \% of Variance & Cumulative \% \\
\hline 1 & 0.779 & 11.135 & 11.135 \\
\hline 2 & 2.551 & 36.439 & 47,574 \\
\hline 3 & 0.840 & 12.000 & 59,574 \\
\hline 4 & 2.110 & 30.142 & 89,716 \\
\hline 5 & 0.560 & 8.001 & 97,717 \\
\hline 6 & 0.096 & 1.368 & 99,085 \\
\hline 7 & 0.064 & 0.914 & 100.000 \\
\hline
\end{tabular}


Pada Tabel 11 dilihat bahwa variabel independent yang paling signifikan terhadap variabel dependent adalah variabel komitmen top management dan kesadaran pekerja dengan nilai total initial equipment lebih dari satu, dengan presentase variansnya masing-masing adalah 36,439\% dan $30,142 \%$, bila presentase keduanya dijumlahkan maka didapatkan nilai presentase sebesar $66,581 \%$. Hal ini berarti dua variabel utama tersebut telah dapat menjelaskan sebesar $66,581 \%$ dari keragaman data yang terjadi. Untuk mendukung pernyataan tersebut diatas akan didukung dengan component transformation matrix pada Tabel 12 dan rotated component matrix pada Tabel 13.

Tabel 12 Component Transformation Matrix

\begin{tabular}{|l|l|l|}
\hline Component & $\mathbf{1}$ & $\mathbf{2}$ \\
\hline 1 & 0.993 & 0.115 \\
\hline 2 & -0.115 & 0.993 \\
\hline
\end{tabular}

Berdasarkan Tabel 12 dapat disimpulkan bahwa sebagian besar keragaman data dari ke-7 variabel dapat dijelas oleh dua variabel, dengan nilai komunitas yang ada 0,115 dan 0,993 .

Tabel 13 Rotated Component Matrix

\begin{tabular}{|l|l|l|}
\hline \multicolumn{3}{|c|}{ Component Matrix } \\
\hline & \multicolumn{2}{|c|}{ Component } \\
\cline { 2 - 3 } & $\mathbf{1}$ & \multicolumn{1}{|c|}{$\mathbf{2}$} \\
\hline Pelatihan K3 & 0.915 & -0.185 \\
\hline Komitmen Top Manajemen & 0.058 & 0.966 \\
\hline Lingkungan Kerja & 0.629 & 0.047 \\
\hline Kesadaran Pekerja & 0.032 & 0.961 \\
\hline Peraturan \& Prosedur K3 & 0.889 & -0.136 \\
\hline Rambu-Rambu K3 & 0.479 & 0.441 \\
\hline Komunikasi Pekerja & 0.541 & -0.070 \\
\hline Extraction Method: Principal Component Analysis. \\
\hline a. 2 components extracted. & \\
\hline
\end{tabular}

Dengan memperhatikan nilai loading faktor yang bernilai lebih dari 0,5 maka berdasarkan Tabel 13 dapat ditentukan interprestasi dari dari dua variabel yang ada pada model yakni komitmen top manajemen dan kesadaran pekerja dengan nilai masing-masing sebesar 0,966 dan 0,961.

\section{b. Uji Korelasi}

Uji korelasi dilakukan untuk mengetahui seberapa kuat hubungan dan membuktikan hipotesis hubungan dua variabel. Berdasarkan hasil analisis komponen/variabel utama yang jelaskan pada Tabel 11 dan Tabel 13 diperoleh dua buah variabel independent (faktor kecelakaan kerja) yang paling signifikan dengan variabel dependepent (kecelakaan kerja) yaitu komitmen top management $\left(\mathrm{X}_{2}\right)$ dan kesadaran pekerja $\left(\mathrm{X}_{4}\right)$.

Sugiono (2011) memberikan pedoman untuk memberikan interprestasi terhadap koefisien korelasi sebagai berikut. 
Tabel 14 Pedoman Untuk Memberikan Interprestasi Terhadap Koefisien Korelasi

\begin{tabular}{|l|l|}
\hline Interval Koefisien & Tingkat Hubungan \\
\hline $0,00-0,199$ & Sangat rendah \\
\hline $0,20-0,399$ & Rendah \\
\hline $0,40-0,599$ & Sedang \\
\hline $0,60-0,799$ & Kuat \\
\hline $0,80-1,000$ & Sangat kuat \\
\hline
\end{tabular}

Dari hasil perhitungan dengan menggunakan SPSS 16.00, diperoleh koefisien korelasi product moment antara komitmen top management $\left(\mathrm{X}_{2}\right)$ dengan kecelakaan kerja $(\mathrm{Y})$, kesadaran pekerja $\left(\mathrm{X}_{4}\right)$ dengan kecelakaan kerja $(\mathrm{Y})$, dan hubungan antara komitmen top management $\left(\mathrm{X}_{2}\right)$ dengan kesadaran pekerja $\left(\mathrm{X}_{4}\right)$, sebagaimana yang akan dijelaskan pada Tabel 15.

Tabel 15 Uji Korelasi Product Moment

\begin{tabular}{|c|c|c|c|c|}
\hline & & $\begin{array}{c}\text { Komitmen } \\
\text { Top } \\
\text { Management }\end{array}$ & $\begin{array}{l}\text { Kesadaran } \\
\text { Pekerja }\end{array}$ & $\begin{array}{c}\text { Kecelakaan } \\
\text { Kerja }\end{array}$ \\
\hline \multirow{5}{*}{$\begin{array}{l}\text { Komitmen Top } \\
\text { Management }\end{array}$} & Pearson Correlation & 1 & $0.933^{* * *}$ & $0.821^{*}$ \\
\hline & Sig. (2-tailed) & & 0.000 & 0.049 \\
\hline & $\begin{array}{l}\text { Sum of Squares and } \\
\text { Cross-products }\end{array}$ & 49.888 & 48.225 & 6.012 \\
\hline & Covariance & 0.631 & 0.610 & 0.076 \\
\hline & $\mathrm{N}$ & 80 & 80 & 80 \\
\hline \multirow{5}{*}{$\begin{array}{l}\text { Kesadaran } \\
\text { Pekerja }\end{array}$} & Pearson Correlation & $0.933^{* *}$ & 1 & 0.812 \\
\hline & Sig. (2-tailed) & 0.000 & & 0.060 \\
\hline & $\begin{array}{l}\text { Sum of Squares and } \\
\text { Cross-products }\end{array}$ & 48.225 & 53.550 & 5.975 \\
\hline & Covariance & 0.610 & 0.678 & 0.076 \\
\hline & $\mathrm{N}$ & 80 & 80 & 80 \\
\hline \multirow{5}{*}{$\begin{array}{l}\text { Kecelakaan } \\
\text { Kerja }\end{array}$} & Pearson Correlation & $0.821^{*}$ & 0.812 & 1 \\
\hline & Sig. (2-tailed) & 0.049 & 0.060 & \\
\hline & \begin{tabular}{|l|} 
Sum of Squares and \\
Cross-products
\end{tabular} & 6.012 & 5.975 & 14.888 \\
\hline & Covariance & 0.076 & 0.076 & 0.188 \\
\hline & $\mathrm{N}$ & 80 & 80 & 80 \\
\hline
\end{tabular}

Berdasar korelasi product moment pada Tabel 4.20 dan dengan membandingkan nilai tersebut tehadap Tabel 15, maka diperoleh hasil sebagai berikut:

1. Korelasi anatara komitment top management dengan kedaran pekerja $\left(\mathrm{r}_{\mathrm{x} 2 \times 4}\right)$ adalah sebesar 0,993, artinya mememiliki hubungan yang sangat kuat.

2. Korelasi anatara komitment top management dengan kecelakaan kerja $\left(\mathrm{r}_{\mathrm{yx} 2}\right)$ adalah sebesar 0,821 , artinya mememiliki hubungan yang sangat kuat.

3. Korelasi anatara kesadaran pekerja dengan kecelakaan kerja $\left(\mathrm{r}_{\mathrm{yx} 4}\right)$ adalah sebesar 0,812, artinya mememiliki hubungan yang sangat kuat. 


\section{Analisis Regresi}

Analisis regresi dilakukan untuk mengetahui hubungan fungsional atau kausal antara dua variabel atau lebih. Berdasarkan Tabel 11 dan Tabel 13 diperoleh dua buah variabel independent (faktor kecelakaan kerja) yang paling signifikan dengan variabel dependepent (kecelakaan kerja) yaitu komitmen top management $\left(\mathrm{X}_{2}\right)$ dan kesadaran pekerja $\left(\mathrm{X}_{4}\right)$. Maka selanjutnya melakukan analisis regresi antara variabel idependent komitmen top management $\left(\mathrm{X}_{2}\right)$ dan kesadaran pekerja $\left(\mathrm{X}_{4}\right)$ dengan varaiabel dependepent (kecelakaan kerja).

Tabel 16 Tabel Uji Regresi Berganda

\begin{tabular}{|c|c|c|c|c|c|c|}
\hline \multirow{2}{*}{\multicolumn{2}{|c|}{ Model }} & \multicolumn{2}{|c|}{$\begin{array}{l}\text { Unstandardized } \\
\text { Coefficients }\end{array}$} & \multirow{2}{*}{ 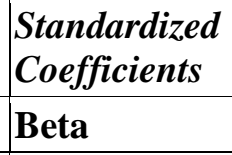 } & \multirow[t]{2}{*}{$\mathbf{t}$} & \multirow[t]{2}{*}{ Sig. } \\
\hline & & B & Std. Error & & & \\
\hline \multirow[t]{3}{*}{1} & $($ Constant $)$ & 0.593 & 0.229 & & 15.723 & 0.000 \\
\hline & $\begin{array}{l}\text { Komitmen } \\
\text { Management }\end{array}$ & 0.364 & 0.169 & 0.179 & 0.580 & 0.002 \\
\hline & Kesadaran Pekerja & 0.301 & 0.163 & 0.045 & 0.144 & 0.001 \\
\hline
\end{tabular}

Berdasarkan Tabel 16 nilai dari:

$A=0,593, b_{1}=0,364, b_{2}=0,301$ dan $F_{\text {hitung }}=3,981, R=0,821 R^{2}=0,674$.

Berdasarkan persamaan 1, maka persamaan regresi untuk hubungan variabel komitmen top management $\left(\mathrm{X}_{2}\right)$ dan kesadaran pekerja $\left(\mathrm{X}_{4}\right)$ dengan variabel kecelakaan kerja (Y) dapat dituliskan sebagai berikut:

$\mathrm{Y}=0,593+0,364 \mathrm{X}_{2}+0,301 \mathrm{X}_{4}$

Untuk semakin meyakinkan hubungan fungsional atau kausal antara variabel komitmen top management $\left(\mathrm{X}_{2}\right)$ dan kesadaran pekerja $\left(\mathrm{X}_{4}\right)$ dengan variabel kecelakaan kerja (Y) maka perlu melakukan uji berikut:

\section{a. Uji Hipotesis Simultan}

Untuk mengetahui apakah secara simultan variabel bebas komitmen top management $\left(\mathrm{X}_{2}\right)$ dan kesadaran pekerja $\left(\mathrm{X}_{4}\right)$ dengan variabel terikat kecelakaan kerja (Y) maka dapat melakukan uji signifikansi dengan hipotesis sebagai berikut:

$\mathrm{H}_{0} \quad$ : tidak terdapat pengaruh yang signifikan anatara variabel bebas $\left(\mathrm{X}_{2}\right.$ dan $\mathrm{X}_{4}$ ) secara bersama-sama dengan variabel terikat $(\mathrm{Y})$.

$\mathrm{H}_{\mathrm{a}} \quad$ : terdapat pengaruh yang signifikan antara variabel bebas $\left(\mathrm{X}_{2}\right.$ dan $\left.\mathrm{X}_{4}\right)$ secara bersama-sama dengan variabel terikat $(\mathrm{Y})$.

Adapapun statistik pengujiannya adalah sebagai berikut:

Jika $\mathrm{F}_{\text {hitung }} \geq \mathrm{F}_{\text {tabel }}$, maka $\mathrm{H}_{0}$ ditolak dan $\mathrm{H}_{\mathrm{a}}$ diterima.

Jika $\mathrm{F}_{\text {hitung }}<\mathrm{F}_{\text {tabel }}$, maka $\mathrm{H}_{0}$ diterima dan $\mathrm{H}_{\mathrm{a}}$ ditolak.

Pengujian regresi antara variabel bebas $\mathrm{X}_{2}$ dan $\mathrm{X}_{4}$ terhadap variabel terikat $\mathrm{Y}$ pada tingkat signifikan 5\%. Jumlah sampel $(\mathrm{N})$ adalah 80 , dan jumlah variabel bebas $(\mathrm{k})$ adalah 2 , sehingga dapa diketahui $\mathrm{dk}$ pembilang $=\mathrm{k}=2$, dan $\mathrm{dk}$ penyebut $=\mathrm{N}-\mathrm{k}-1=77$. Setelah $\mathrm{dk}$ pembilang dan $\mathrm{dk}$ penyebut diketahui, maka didapatkan nilai $\mathrm{F}$ tabel sebesar 2,92 dan $\mathrm{F}_{\text {hitung }}$ sebesar 3,981. Karena $\mathrm{F}_{\text {hitung }}>$ dari $\mathrm{F}_{\text {tabel}}$, maka $\mathrm{H}_{0}$ ditolak dan $\mathrm{H}_{\mathrm{a}}$ diterima yang artinya terdapat 
pengaruh yang signifikan antara variabel bebas $\left(\mathrm{X}_{2}\right.$ dan $\left.\mathrm{X}_{4}\right)$ secara bersamasama dengan variabel terikat (Y).

\section{b. Uji Hipotesis Parsial}

Uji signifikansi dengan hipotesis parsial sebagai berikut:

$\mathrm{H}_{0} \quad$ : tidak terdapat pengaruh yang signifikan antara variabel bebas $\left(\mathrm{X}_{2}\right.$ dan $\mathrm{X}_{4}$ ) secara bersama-sama dengan variabel terikat (Y).

$\mathrm{H}_{\mathrm{a}} \quad$ : terdapat pengaruh yang signifikan antara variabel bebas $\left(\mathrm{X}_{2}\right.$ dan $\left.\mathrm{X}_{4}\right)$ secara bersama-sama dengan variabel terikat (Y).

Adapapun statistik pengujiannya adalah sebagai berikut:

Jika - $\mathrm{t}_{\text {tabel }}>\mathrm{t}_{\text {hitung }}>\mathrm{t}_{\text {tabel }}$, maka $\mathrm{H}_{0}$ ditolak dan $\mathrm{H}_{\mathrm{a}}$ diterima.

Jika $-\mathrm{t}_{\text {tabel }} \leq \mathrm{t}_{\text {hitung }} \leq \mathrm{t}_{\text {tabel }}$, maka $\mathrm{H}_{0}$ diterima dan $\mathrm{H}_{\mathrm{a}}$ ditolak.

Berdasarkan Tabel 16 didapat $\mathrm{t}_{\text {hitung }}$ untuk variabel bebas komitmen top management sebesar 0,580 , bila dibandingkan dengan nila $t_{\text {tabel }}$ dengan taraf signifikan $5 \%$ dan $\mathrm{dk}=\mathrm{N}-2=78$ diperoleh nilai $\mathrm{t}_{\text {tabel }}$ sebesar 1,669. Karena $1,669 \leq 0,580 \leq 1,669$, maka $\mathrm{H}_{0}$ ditolak dan $\mathrm{H}_{\mathrm{a}}$ diterima, artinya terdapat pengaruh yang signifikan antara variabel bebas $\left(\mathrm{X}_{2}\right.$ dan $\left.\mathrm{X}_{4}\right)$ secara bersamasama dengan variabel terikat $(\mathrm{Y})$.

\section{KESIMPULAN DAN SARAN}

\section{A. Kesimpulan}

Berdasarkan hasil penelitian yang telah dilakukan maka diperoleh kesimpulan sebagai berikut:

1. Faktor-faktor yang mempengaruhi terjadinya kecelakaan kerja adalah pelatihan keselamatan dan kesehatan kerja $\left(\mathrm{X}_{1}\right)$, komitmen top manajemen $\left(\mathrm{X}_{2}\right)$, lingkungan kerja $\left(\mathrm{X}_{3}\right)$, kesadaran pekerja $\left(\mathrm{X}_{4}\right)$, peraturan dan prosedur keselamatan dan kesehatan kerja $\left(\mathrm{X}_{5}\right)$, tersedianya rambu-rambu keselamatan dan kesehatan kerja $\left(\mathrm{X}_{6}\right)$ di tempat kerja, dan komunikasi pekerja $\left(\mathrm{X}_{7}\right)$. Selain dari ketujuh faktor tersebut kecelakaan kerja juga bisa dipengaruhi oleh tingkat pengalaman kerja.

2. Faktor yang paling signifikan mempengaruhi terjadinya kecelakaan kerja adalah komitmen top manajemen $\left(\mathrm{X}_{2}\right)$ dengan nilai koefien regresi sebesar $36,4 \%$ dan kesadaran pekerja $\left(\mathrm{X}_{4}\right)$ sebesar $30,1 \%$. Bila kedua faktor tersebut dijumlahkan totalnya adalah 66,5\% sedangan 33,5\% disebabkan oleh faktor-faktor yang lain yaitu pelatihan keselamatan dan kesehatan kerja $\left(\mathrm{X}_{1}\right)$, lingkungan kerja $\left(\mathrm{X}_{3}\right)$, peraturan dan prosedur keselamatan dan kesehatan kerja $\left(\mathrm{X}_{5}\right)$, tersedianya ramburambu keselamatan dan kesehatan kerja $\left(\mathrm{X}_{6}\right)$ di tempat kerja, dan komunikasi pekerja $\left(\mathrm{X}_{7}\right)$.

3. Cara untuk meminilisir terjadinya kecelakaan kerja pada proyek konstruksi yakni pihak manajemen bertanggung jawab mengembangkan dan mempertahankan suatu program pencegahan terjadinya kecelakaan kerja dan meningkatkan pratik-pratik kerja dan kondisi-kondisi yang aman sedangkan karyawan mempunyai tanggung jawab untuk melindungi keselamatan dan kesehatan diri sendiri serta orang lain yang kemungkinan mendapat akibat dari tindakan atau kelalaian yang dilakukannya, termasuk hal-hal berikut.

a. Mematuhi semua perintah dan peraturan keselamatan kerja.

b. Menggunakan Alat Pelindung Diri (APD) perseorangan.

c. Ikut merawat dengan baik semua peralatan safety yang berfungsi untuk melindungi keselamatan bersama.

d. Menginformasikan kepada pihak manajemen apabila ingin mencabut peralatan keselamatan kerja di tempat kerja.

e. Memasang kembali peralatan keselamatan kerja di tempat kerja apabila telah selesai melakukan pekerjaan. 
f. Melaporkan semua bahaya di tempat kerja.

g. Melaporkan semua cidera akibat kerja.

h. Bekerja sama dengan atasan, sesama teman kerja lain, dan kepada bawahan.

\section{B. Saran}

Saran yang bisa diberikan adalah sebagai berikut:

1. Sebaiknya pihak manajemen selalu memberikan motivasi dan dorongan kepada karyawan untuk selalu menggunakan Alat Pelindung Diri (APD).

2. Setiap karyawan diwajibkan selalu menggunakan APD pada saat bekerja, dan tidak menganggap bahwa APD akan menurunkan perfoma kerja melainkan untuk meningkatkan produktivitas dan melindungi karyawan dari penyakit akibat kerja.

3. Semua pihak yang terlibat dalam proyek konstruksi selalu mengutamakan dan memprioritaskan Keselamatan dan Kesehatan Kerja (K3).

\section{DAFTAR PUSTAKA}

[1] Akpan, E.I., 2011, Effective Safety and Health Management Policy for Improved Performance of Organizations in Africa, International Journal of Business and Management, Vol. 6, No. 3, University of Calabar, Nigeria.

[2] Bulannurdin, R.N., dan Sugiyarto, 2012, Analisis Pengaruh Keselamatan dan Kesehatan Kerja (K3) Terhadap Kinerja Pekerja Konstruksi, e-Jurnal Matriks Teknik Sipil, Universitas Sebelas Maret, Surakarta.

[3] Cristina, W.Y., dkk, 2012, Pengaruh Budaya Keselamatan Dan Kesehatan Kerja (K3) Terhadap Kinerja Proyek Konstruksi, Jurnal Rekayasa Sipil/Volume 6, no. 1 - 2012 ISSN 1978 - 5658, Universitas Brawijaya Malang, Malang.

[4] Dessler, G., 1997, Manajemen Sumber Daya Manusia, PT. Prenhallindo, Jakarta.

[5] Ervianto, W.I., 2005, Manajemen Proyek Konstruksi, ANDI Yogyakarta, Yogyakarta.

[6] Santoso, S., 2001, Statistic Non Parametric, Gramedia, Jakarta.

[7] Sepang, B. A.W., 2013, Manajemen Risiko Keselamatan dan Kesehatan Kerja (K3) Pada Proyek Pembangunan Ruko Orlens Fashion Manado, Jurnal Sipil Statik Vol.1 No.4, Maret 2013 (282-288) ISSN: 2337-6732, Universitas Sam Ratulangi, Manado.

[8] Smith, A., and Sonesh, S., 2011, How Hazards and Safety Training Influence Learning and Performance, Journal of Applied Psychology 2011 American Psychological Association Vol. 96, No. 1, 46-70 0021-9010/11/\$12.00 DOI: 10.1037/a0021838, Tulane University, Amerika.

[9] Suharsimi Arikunto, 2006, Prosedur Penelitian, PT. Rineka Cipta, Jakarta.

[10] Sugiyono, 2011, Statistika Untuk Penelitian, Alfabeta, Bandung.

[11] Suma'mur, K.P., 1996, Keselamatan Kerja Dan Pencegahan Kecelakaan, PT. Toto Gunung Agung, Jakarta.

[12] Taderera, H., 2011, Occupational Health and Safety Management Systems:Institutional and Regulatory Frameworks in Zimbabwe, International Journal of Human Resource Studies ISSN 2162-3058 100 2012, Vol. 2, No. 4, University of Zimbabwe, Zimbabwe. 